\title{
EFFECT OF CORN SILK-BOILED WATER ON CHOLESTEROL LEVEL IN PATIENTS WITH HYPERCHOLESTEROLEMIA
}

\author{
IN BANDUNG, WEST JAVA \\ Budiman ${ }^{1)}$, Rachmi Laila Puspasari ${ }^{2)}$ \\ 1) Undergraduate Program in Public Health, School of Health \\ Sciences (STIKES) Ahmad Yani, Cimahi \\ 2) Undergraduate Program in Nursing, School of Health \\ Sciences (STIKES) Ahmad Yani, Cimahi
}

\begin{abstract}
BACKGROUND: Corn silk is a traditional medicine that has been identified to contain protein, carbohydrates, vitamins, minerals, and fiber. It also contains chemicals which might work like water pills (diuretics), and it might alter blood sugar levels, and help reduce inflammation. Corn silk has been used for bladder infections, inflammation of the urinary system, inflammation of the prostate, kidney stones, and bedwetting. It is also used to treat congestive heart failure, diabetes, high blood pressure, fatigue, and high cholesterol levels. Hypercholesterolemia is a condition characterized by an increased level of blood cholesterol $>200 \mathrm{mg} / \mathrm{dL}$. Hypercholesterolemia contributed to approximately 4.4 million or $7.9 \%$ mortality rate in the world annually. This study aimed to examine effect of corn hair-boiled water on cholesterol level in patients with hypercholesterolemia.
\end{abstract}

SUBJECT AND METHODS: This was a quasi-experimental with one group pretest-posttest design. This study was conducted in UPT Puskesmas Telaga Bodas, Bandung. A sample of 12 patients with hypercholesterolemia was selected for this study. The different in mean cholesterol level before and after treatment was analyzed using paired $t$ test.

RESULTS: The cholesterol level decreased from before to after treatment by $14.92 \mathrm{mg} / \mathrm{dL}(\mathrm{p}=0.001)$.

CONCLUSION: Consumption of corn silk-boiled water can reduce blood cholesterol in patients with hypercholesterolemia.

Keywords: hypercholesterolemia, corn silk-boiled water, traditional medicine 